\title{
Intellectual property and the organization of information production
}

\author{
Yochai Benkler* \\ Professor of Law, New York University School of Law, 40 Washington Square South, \\ New York, NY 10012, USA
}

Accepted 19 February 2002

\begin{abstract}
This paper analyzes an area that economic analysis of intellectual property has generally ignored, namely, the effects of intellectual property rights on the relative desirability of various strategies for organizing information production. I suggest that changes in intellectual property rules alter the payoffs to information production in systematic and predictable ways that differ as among different strategies. My conclusion is that an institutional environment highly protective of intellectual property rights will (a) have less beneficial impact, at an aggregate level, than one would predict without considering these effects, and (b) fosters commercialization, concentration, and homogenization of information production, and thus entails normative implications that may be more salient than its quantitative effects. (C) 2002 Published by Elsevier Science Inc.
\end{abstract}

Keywords: Economic analysis; Intellectual property; Information production

\section{Introduction}

As information production has become more central to our economy, we have seen a Cambrian Explosion of exclusive private rights in information. The past half decade has seen the term of copyright extended, patents granted in business methods, property rights sought for compilations of raw data, trademark morph from a confusion-prevention law to a goodwill-retention law, and a vast increase in the legal effect of privately created and enforced exclusion - created by contract and enforced by technology. In this article I explain

* Tel.: +1-212-998-6738; fax: +1-212-995-4341.

E-mail address: yochai.benkler@nyu.edu (Y. Benkler). 


\begin{tabular}{|ll|}
\hline Nomenclature \\
$I$ & information \\
$I_{\mathrm{pd}}$ & information in the public domain \\
$I_{\text {intrafirm }}$ & information owned by the firm making a production decision \\
$I_{\mathrm{m}}$ & owned information available from the market \\
$I_{\mathrm{b}}$ & owned information available in barter \\
$C$ & costs of information production \\
$C_{\mathrm{h}}$ & human capital costs \\
$C_{\mathrm{i}}$ & information input costs \\
$C_{\mathrm{m}}$ & cost of information available from markets \\
$\mathrm{C}_{\mathrm{m}}$ & cost of information available from public domain or intrafirm sources \\
$C_{\mathrm{b}}$ & cost of information available in barter \\
$C_{\mathrm{comm}}$ & cost of communicating information \\
$B_{\mathrm{i}}$ & benefits of information production \\
$B_{\mathrm{d}}$ & benefits acquired by direct appropriation \\
$B_{\mathrm{d}}$ & benefits acquired by indirect appropriation \\
\hline
\end{tabular}

why strong intellectual property rights such as these are systematically less beneficial in terms of increasing aggregate information production than usually thought, and why they are likely to lead to commercialization, concentration, and homogenization of information production.

Economic analysis of intellectual property falls, broadly speaking, into two main clusters: welfare economics ${ }^{1}$ and neo-Schumpeterian economics of innovation. ${ }^{2}$

The neo-Schumpeterian literature focuses on the relationship between market structure and investment in innovation. ${ }^{3}$ This literature typically treats the market structure in which an information producer operates as the primary determinant of information production activity, rather than focusing on the incentive effects of legal rights. This paper shares with this literature a concern for the relationship between information production and the organization of production, but looks not at the relationships between market structure at the macro level and innovation, but at the relationship between legal rules and the organization of production at the micro level.

Welfare economics of intellectual property has three primary sub-clusters. The first subcluster, rooted in the work of Arrow ${ }^{4}$ and Nordhaus, ${ }^{5}$ focuses on the welfare tradeoffs between the incentives created by property rights and the social cost of enforcing rights-both the costs of administering the system and, more importantly, the cost of losing access to information-a non-rival public good-at its marginal cost of zero. ${ }^{6}$ This tradeoff is often seen as involving static losses (in consumption of existing information offered at an above-marginal cost price sufficient to compensate producers) and dynamic gains (through incentives to invest in production), but the effects on second generation producers who use information as an input into their own productive enterprise adds a dynamic loss as well. ${ }^{7}$ This paper is largely situated in this sub-cluster. 
The second sub-cluster follows Demsetz, focusing on the signaling effect of property rights-whereby consumers signal producers what innovations or information goods are most valuable. ${ }^{8} \mathrm{~A}$ variant of this argument focuses on private parties' advantage in reaching efficient tradeoffs between incentives and access using property-based contracts. ${ }^{9}$ A central difference between the first and second sub-clusters is that the first treats limitations on rights-like fair use - as inherent elements in fine tuning rights to achieve optimal protection, while the second justifies such limits only insofar as necessary to overcome market failures-primarily those based on transaction costs. ${ }^{10}$ The third and final sub-cluster analyzes the ways in which intellectual property rights can cause or limit inefficient over-investment and uncoordinated production. ${ }^{11}$

This paper operates largely within the first sub-cluster of welfare economics treatments of intellectual property, but adds one aspect that has not been the focus of prior work. I take the basic parameters of this sub-cluster and apply them to the question of how intellectual property rules affect the business strategies used by information producers. In particular, I explain why strong property rights prefer certain kinds of information producers, like Disney and Time Warner, to other kinds of information producers, like Tim-Bernhers Lee who developed the WWW, Kenneth Arrow, or the Electronic Frontier Foundation. I also suggest why Disney-like producers are likely to over-invest in repackaging Mickey Mouse cartoons, or more generally why those who benefit most from strong intellectual property are likely to misapply talent to information inputs. Recognizing this effect also differs from the approach used in empirical literature that studies information production strategies, because that literature describes how firms actually use (or don't) property rights, but does not attempt to define analytically the relationship between the structure of property rights and the strategic choices of firms. ${ }^{12}$

My analysis relies on assumptions and observations commonly accepted in the welfare economics literature in this area, and which drive the analysis of the Arrow/Nordhaus subcluster. Information is a public good. Once produced, it is purely non-rival and partially nonexcludable. ${ }^{13}$ Moreover, information is both input and output of its own production process. ${ }^{14}$ Consistent application of these observations suggests that intellectual property rights have systematic predictable effects on the payoffs from various strategies for organizing information production. The effects I identify are entirely derived from these basic observations, and are therefore independent of and cumulative with transaction costs effects on the incentives of information producers.

Section 2 uses examples from software and genomics to introduce the basic intuition that, if information producers use diverse strategies to acquire information inputs and manage information outputs, then intellectual property has different effects on different strategies. Section 3 develops an ex ante analysis of how this diversity arises and how changes in intellectual property are likely to affect payoffs to various strategies. Section 4 abstracts from this model nine ideal-type strategies that organizations use to produce information, which accords with the empirical literature that describes information production. Section 5 suggests how changes in intellectual property rights affect the payoffs to these strategies in predictable ways. Increased protection makes some strategies more attractive and others less so. Specifically, increased protection benefits commercial information producers that vertically integrate new production with management of large-scale owned inventories of existing information, and that have incentives systematically to misapply human capital to information resources. This benefit comes 
at the expense of alternative strategies, both commercial and non-commercial. In Section 6, I note a series of feedback effects likely to result from the shifts in organizational strategies that the analysis in Section 5 predicts. These feedback effects will likely amplify, speed up, and lock in the effects of the changes in payoffs identified in Section 5.

Section 7 explains the two primary policy implications of this analysis. First, intellectual property rights will systematically yield less of their desired effects than usually predicted by models that do not consider divergent effects on different strategies. Second, intellectual property policy has an irreducibly normative element. Strong intellectual property rights tend to lead towards commercialization and concentration of information production, and to a certain type of inefficient homogenization of the information produced. Whether these effects are desirable or not, and if undesirable, whether they are worth the quantitative increase in outputs that results from stronger protection, is a normative question that cannot be resolved within economic analysis.

\section{Recognizing diversity in information production strategies}

The diversity of information production strategies, the competition among them, and the divergent effects that intellectual property rules have on them can be illustrated at an intuitive level by examples from the software and genomics industries.

Computer communications and software are a sector in which strategies that do not depend on intellectual property have often outperformed those that do. TCP/IP and the public network model of the Internet overwhelmed proprietary networks like Prodigy, Compuserve, and MSN. Ethernet was developed at Xerox PARC as a public standard intended to enhance networking. It became the dominant LAN standard despite IBM's attempt to establish its proprietary Token Ring standard in the 1980s. The World Wide Web was developed by a scientist then working at CERN, Tim Bernhers Lee, as a device to share information with and among colleagues. Lee treated the standard from its inception as public, and current standard setting is achieved through a non-commercial body-the $\mathrm{W} 3 \mathrm{C}$. The Web, rather than a coeval proprietary program like Lotus Notes, became the standard for document sharing.

Most telling about the force of non-proprietary approaches to software development is the remarkable success of free or open source software. Among many other programs, these strategies are responsible for the Apache Web server software, whose growth exceeded that of competing commercial products between 1995-2000, and is used by over $60 \%$ of web servers, ${ }^{15}$ Sendmail, an open source e-mail relay program, used by over $75 \%$ of Internet mail servers, and the most widely known product of the Free Software movement, the GNU/Linux operating system. ${ }^{16}$

Open source development relies heavily on communication among volunteer users/ developers. ${ }^{17}$ A person or group may write software to perform a function, usually to serve a need they have as users. Other users are invited to use the software, and when they develop needs unfulfilled by the program, they post questions to mailing lists dealing with the particular type of software, and either they, or (usually) someone else in the network of users/developers, will provide a fix. To maintain the ability of users to add and develop the software, while retaining the benefits of these downstream additions for all those who preceded them, open 
source software is distributed with its source code, subject to a license: that permits redistribution, whether by sale or gift; permits derivative works if these are distributed under the terms of the original license; and allows authors to control integrity of the original code as a unit, but does not constrain parallel distribution of modifications. ${ }^{18}$ These elements limit the ability of developers to appropriate the benefits of production by asserting intellectual property rights. Individuals and organizations that use this strategy must instead follow indirect appropriation strategies that do not rely on asserting rights.

Free and open source strategies appear to have been particularly effective at producing robust, well-tested software. This is apparently so because this approach enlists a wide-ranging international community of developers operating from a variety of incentives-reputation, hobby, political commitment, or associated businesses-who test, improve, and service the software on a scale, at a rate, and with efficiency that cannot be replicated even by the largest software manufacturers. While the individual investment of most participants may be lower than that of any single developer in a commercial model, the combined efforts of individuals who use the product and contribute pertinent local solutions to the complex system appears to produce better solutions more rapidly than possible in more centralized production models.

The potential conflict between open source and direct-appropriation strategies was most clearly stated in an internal Microsoft memo known as the "Halloween Memo." 19 There, the author suggested that Microsoft could compete with open source by developing new proprietary standard interfaces that would be necessary for Linux to interoperate with Microsoft-compatible products, and then to deny Linux developers access to those interfaces. ${ }^{20}$ The point is that while assertion of property rights in necessary inputs-like standard interfaces - can plainly harm non-proprietary software development, strong intellectual property protection holds little value for it.

Equally revealing about the relative efficacy and importance of production strategies that suffer from increases in intellectual property is the one told by Rebecca Eisenberg about the Human Genome Project, and the competing strategies for pursuing complimentary DNA (cDNA) sequencing. ${ }^{21}$ Developers have adopted a series of business strategies, ranging from highly property rights reliant ${ }^{22}$ to release of the information into the public domain in expectation of future associated revenues. ${ }^{23}$ Particularly interesting is Eisenberg's description of Merck \& Co.'s incentives for investing in a database dedicated from its inception to the public domain. "Merck's comparative advantage does not lie in performing this fundamental research, but rather in developing specific drugs at a later stage in the research and development process. By promptly placing the sequence information in the public domain, and thereby making it widely available to academic researchers, Merck anticipates benefiting in the long run from the fundamental research of those who use the database .... From Merck's perspective, cDNA sequences are research tools for use in drug discovery, not products for sale to consumers. For HGS and Incyte, cDNA sequences are themselves a product ....". ${ }^{24}$

It is important to note that Merck's indirect appropriation strategy-funding information production access to which will give Merck production advantages in its core marketscannot, by itself, sequence genes. The strategy relies on academic researchers, giving them access to inputs they need in order to sequence new genes. These researchers, in turn, appropriate the value of their information production through personal gains-reputational, educational, hedonic — or through grant-funding and teaching tied to their information production. 
These forms of funding are tied to publication in scientific journals, which, in turn, reinforce the public domain focus of the academic model by requiring scientists who publish to make their methods and materials freely available to other scientists. ${ }^{25}$

These examples cannot establish whether proprietary or non-proprietary approaches to production are more efficient in software or genomic research. They suggest, however, a tension between the interests of organizations engaged in similar information production activities, based on how they organize production. It is this tension that this paper is concerned with.

\section{Intellectual property rights and the costs and benefits of information production}

\subsection{Specifying the costs and benefits of information production}

I assume that information producers are rational, well informed about their expected costs and benefits, and engage in information production to maximize the difference between their costs (including opportunity cost of engaging in information production) and benefits. ${ }^{26} \mathrm{I}$ use the assumption that human capital ${ }^{27}$ and existing information are the most important inputs into information production, ignoring capital and labor in the more traditional sense. ${ }^{28}$ I use the notations in the discussion for expositional clarity alone; they do not offer mathematical support for my claims.

The body of information available in a society at a given moment for use as input into new production, $I$, is comprised of information that is either owned or unowned. Owned information is all owned by someone, so any piece of owned information is, for some firm (or individual), owned by it, $I_{\text {intrafirm}}$. All unowned information is information in the public domain, ${ }^{29} I_{\mathrm{pd}}$. For each firm, all owned information that it does not own is available only through transactionseither by purchase at market price $\left(I_{\mathrm{m}}\right)$ or through sharing or barter $\left(I_{\mathrm{b}}\right)$. So the universe of available information inputs is seen by each firm as composed of $I=I_{\mathrm{pd}}+\left[I_{\text {intrafirm }}+I_{\mathrm{m}}+I_{\mathrm{b}}\right]$. It is obvious that at any given moment the availability of information from the public domain and the availability of information that is owned by someone are inversely related. Furthermore, the larger a firm's information endowment the less it must purchase or barter for information from the universe of owned information.

The costs of information production $C$ are the sum of the costs of human capital $C_{\mathrm{h}}$ and of the cost of information inputs $C_{\mathrm{i}}$. Intellectual property rights affect $C$ by affecting the value of $C_{\mathrm{i}}$. To the extent that the ratio between $C_{\mathrm{i}}$ and $C_{\mathrm{h}}$ is very low, changes in property rights will have a relatively low effect on the value of $C$, and hence would have a limited effect on production costs. ${ }^{30}$ But even poets borrow from the works of other poets, and I assume that most activity would fall within Kuhn's concept of "normal science," and that for such incremental information production the ratio between $C_{\mathrm{i}}$ and $C_{\mathrm{h}}$ is high enough such that the effects of intellectual property on the magnitude of $C_{\mathrm{i}}$ are large enough to affect $C$. For purposes of this paper I assume that the ratio between the quantity of information inputs and the quantity of human capital used in producing an information product is exogenous (say, determined by the nature of the information product and the way in which the discipline of producing this type of information mixes information inputs with creative talent). ${ }^{31}$ 
$C_{\mathrm{i}}$ is comprised of the cost of information inputs available at a positive, above-marginal cost market price ${ }^{32}\left(I_{\mathrm{m}}\right.$ available at $\left.C_{\mathrm{m}}\right)$, those available at marginal cost from non-market sources, $\left(I_{\mathrm{m}}\left(=I_{\mathrm{pd}}+I_{\text {intrafirm }}\right)\right.$ at $\left.C_{\mathrm{m}}(=0)\right)$ and those available by bartering or sharing with other firms $\left(I_{\mathrm{b}}\right.$ at $\left.C_{\mathrm{b}}\right),{ }^{33}$ and the cost of communicating information inputs from those who have them to those who do not $\left(C_{\text {comm }}\right){ }^{34} C_{\mathrm{i}}=C_{\mathrm{m}}+C_{\mathrm{m}}+C_{\mathrm{b}}+C_{\text {comm }}$. A firm will seek to minimize its costs by using, to the extent possible, inputs available at $C_{\mathrm{m}}$. In order to explain why any owned information inputs would be purchased at $C_{\mathrm{m}}$ while there exist inputs from non-market sources, I assume that there is heterogeneity in the suitability of inputs to producing a given new product, given available human capital. I further assume that any given existing input has a probability of being the best input to be combined with available human capital to produce a product, and that this probability is independent of that input's being owned or unowned, or owned by the firm making the decision or another firm. ${ }^{35}$ I assume that a firm knows the probability that the input will be the right input, and that its probability assessment is what causes the firm to pay a positive price given the availability of other inputs from non-market sources. ${ }^{36}$ I also assume that the cost of communicating the information is independent of whether the information is sold or given away for free ${ }^{37}$ Note that if communication costs are very high, the consequences of my analysis are muted just as they would be if human capital costs were disproportionately high. Inversely, as communication costs decline, the importance of the effects of property rights on information input costs increases.

It should now be fairly intuitive to see how increases in the scope and content of intellectual property increase the cost of information production. A change in law that increases property rights, say, an extension of the term of copyright protection so that information that would have been in the public domain continues to be owned for another 20 years, ${ }^{38}$ decreases the quantity of inputs $I_{\mathrm{pd}}$ available at $C_{\mathrm{m}}$. Inputs that, but for the change in law, would have been available at $C_{\mathrm{m}}$, will now be available only at the higher $C_{\mathrm{m}}$ or $C_{\mathrm{b}}$, unless the firm happens to own them. Unless the firm owns the inputs enclosed by the change in law, then, it will see a rise in $C_{\mathrm{i}}$.

Benefits of information production $B_{\mathrm{i}}$ can be directly or indirectly appropriated. By "direct" appropriation $B_{\mathrm{d}}$ I mean sale of the producer's agreement to abstain from excluding the buyer from the firm's information outputs. ${ }^{39} \mathrm{~A}$ firm relying solely on direct appropriation would sell access to its information products at least at a price sufficient to cover its production costs, including compensating for failed attempts - the optimal supply price — or at a premium above that price to the extent that it has market power because of a lack of substitutability for its information goods.

"Indirect" appropriation $B_{\mathrm{d}}$ is a residual category-any means by which the producer can obtain a benefit from producing the information other than sale of permission to access it. ${ }^{40}$ Indirect appropriation can be attained from both market and non-market sources. It could be attained by correlative gains in the sale of another product or service whose sales increase as a result of the information production. These gains could be supply-side effects in the correlated market, where the producer itself gains advantage through early access to the informationas in the case of industrial R\&D where first mover advantages can convert early access to information into a production and sales advantage. They could also be demand-side effects, because access to the information by others leads to increased demand for the other product or service offered by the information producer. 
Indirect appropriation can also rely on non-market institutions, like grant-funding, whether carried on by individuals or organizations. Individual creators might see educational and reputation gains, and might also have a taste for creation, so that at least some benefit is hedonic. Any academic who could command higher income in practice has chosen to prefer some combination of education, reputation, and hedonic gains in exchange for reduced direct payment.

Information production will be sustainable throughout the ranges in which $B_{\mathrm{i}}>C$ or $B_{\mathrm{d}}+B_{\mathrm{d}}>C_{\mathrm{h}}+C_{\mathrm{m}}+C_{\mathrm{m}}\left(I_{\mathrm{pd}}+I_{\text {intrafirm }}\right)+C_{\mathrm{b}}+C_{\text {comm }}$. In other words, the sum of direct and indirect benefits must exceed the costs of human capital, the costs of information inputs: owned by others and available at market price, owned by the producer or unowned (in the public domain) and available at marginal cost, or owned by another firm and obtained through sharing or barter, and the costs of communicating these information inputs to the firm that intends to use them.

\subsection{Effect of property rights on costs and benefits}

If no property rights were recognized, direct appropriation would be impossible, and the condition for information production would be $B_{\mathrm{a}}>C_{\mathrm{h}}+C_{\mathrm{m}}\left(I_{\mathrm{pd}}\right)+C_{\mathrm{comm}}$. In other words, in the absence of property rights some combination of indirect gains must cover the cost of human capital and of communicating information from those who have it to those who do not. This is hardly an earth-shattering revelation, but it underscores that where the marginal cost of one major input is zero and the other major input involves individual creativity, low-cost, low-returns strategies are a sustainable production strategy. This is the essence of the claim that people develop Linux for "egoboo." ${ }^{41}$ It is consistent with the claim that the scientific revolution that followed the invention of print was catalyzed by a drastic reduction in communication costs, which permitted many copies to travel to readers instead of requiring readers to travel to single manuscripts. This dramatic decline in the cost of communication of inputs into inquiry has been credited with such modest innovations of that age, which preceded the invention of intellectual property rights, as the Copernican Revolution. ${ }^{42}$

The introduction of property rights is what introduces $B_{\mathrm{d}}, I_{\mathrm{m}}$ at $C_{\mathrm{m}}, I_{\text {intrafirm }}$ at $C_{\mathrm{m}}$, and $I_{\mathrm{b}}$ at $C_{\mathrm{b}}$, into the equation. This is done by limiting availability of inputs of the $I_{\mathrm{pd}}$ variety. Again, it is easy to see that increasing intellectual property rights makes sense only so long as the increase permits a greater increase in $B_{d}$ than in the sum of $C_{\mathrm{m}}, C_{\mathrm{m}}\left(I_{\mathrm{pd}}+I_{\text {intrafirm }}\right)$, and $C_{\mathrm{b}}$. As the public domain shrinks, a greater proportion of inputs must be purchased at $C_{\mathrm{m}}$, unless the firm has a large inventory of existing information and can increase utilization of $I_{\text {intrafirm }}$ at $C_{\mathrm{m}}$ rather than $I_{\mathrm{m}}$ at $C_{\mathrm{m}}$. Furthermore, to the extent that the likelihood that any given information input will be useful today is independent of how it was produced yesterday (i.e., out of public domain or owned inputs; by a producer that relies primarily on direct or indirect benefits), an increase in property rights increases the expected cost of information production for all producers. Producers that before the change relied solely on indirect benefits face higher costs, but gain no benefit, because an increase in protection increases only $B_{\mathrm{d}}$, not $B_{\mathrm{d}}$.

Another implication is that information inventories are likely to exhibit scope economies in the face of an increase in property rights, because a larger inventory represents more varied inputs available at marginal cost for a given pool of human resources. The larger and more 
diverse an inventory, the higher the probability that an input necessary to produce a new piece of information will be in it. (This relies on the assumption that the probability of a given input's utility to new production is independent of whether that input is owned or unowned, by the firm or another firm). Two organizations that combine their creative workforces and give each member of the combined workforce access to the joint inventory are likely to have better suited information inputs available at marginal cost to use in a given project than the same two organizations when each workforce utilizes only its organization's independently-owned inventory. ${ }^{43}$ This effect is cumulative to the more obvious benefit of integration, that it avoids transaction costs associated with purchase of information inputs owned by others. Its importance increases as the public domain shrinks and intrafirm sources become increasingly important sources of information inputs at marginal cost.

The detailed specification of costs and benefits suggest that increases in the scope of intellectual property rights have very different implications for organizations that appropriate the benefits of information production indirectly than for those that appropriate benefits directly, as the following example illustrates. Imagine that law changes from a rule that permits researchers to make personal-use photocopies of single articles from journals to which the organization in which they are employed subscribes, to one that requires them to pay royalties for each photocopy. ${ }^{44}$ Assume that photocopying without a royalty is free and that the royalty is transferred with no loss to transaction costs (these assumptions mildly simplify, but do not change the analysis). Imagine that every journal subscription costs $\$ 100$ and each journal has 10 articles; the photocopying royalty is $\$ 1$ per article copied; and an efficient researcher needs repeated immediate access (of the type obtained from having your own copy) to 10 prior articles in order to produce a new article. An organizational librarian has a $\$ 10,000$ budget to serve 100 researchers. Before the change in law, the librarian subscribes to 100 different journals and photocopies the 10 articles needed by researchers for each new work they produce (I assume that the original journal must be kept available for others to read other articles in it). Each researcher had 1000 different articles from which to choose as his or her 10 repeat-access articles for a new article. After the change in law, if the organization owns none of the journals, the increased cost for each production cycle of one new article per researcher in the organization would be 10 (articles) $\times \$ 1$ (royalty) $\times 100$ (researchers $)=1000$. The library could adopt any combination of three basic solutions to cover the new cost: (1) buying 90 journals for $\$ 9000$, reserving $\$ 1000$ for photocopying, and reducing the number of articles available as inputs for researchers to 900 ; (2) buying 100 journals, but providing researchers with no photocopies of articles, so they have degraded access to the same amount of inputs and must queue for repeated access, delaying production and perhaps degrading quality because of unwillingness to wait; and (3) increasing the budget by $\$ 1000$.

If, say, the library serves a non-profit research institute that circulates its products as a working paper series at print and postage (communication) cost, increased protection entails no increased returns. Unless it can increase its budget from unrelated sources, the library must either decrease quality of access to the same information inputs (by time delay through making fewer personal copies available) or decrease the quantity of information inputs available to its clients at the same quality (by making the same number of personal copies available, but holding fewer journals). 
A commercial journal that provides commentary written by its staff will experience similar increases in input costs to its staff for access to other publications. Imagine the same size human capital pool and information input needs, and the same budget of $\$ 10,000$ generated from sale of 100 copies of its journal at $\$ 100$ each. Its new photocopying cost will be $\$ 1000$. The journal is indifferent to the new rule if on average each of the 10 articles in each issue is photocopied by 100 researchers who are not part of the organization, so that photocopying royalty payments completely cover the increased cost of inputs. If it expects more unaffiliated researchers to need personal-use copies of its articles, then it sees a net gain from the change in law.

Now, imagine that the commercial journal is owned by Elsevier, which publishes over 2,000 journals. Imagine that four of the ten journal articles to which each of its 100 in-house researchers need access are in Elsevier journals, and hence available royalty-free from intrafirm sources. The new photocopying royalty costs for each new article written would be only $\$ 6$, and for the whole journal $\$ 600$, compared with the $\$ 1000$ spent by the independent journal or non-profit institute. In other words, by being part of a larger organization that owns a lot of the information likely to be useful as input into new production, the journal is more likely to get the benefit of the new right to photocopying royalties without incurring much of its cost. On average, only 60 unaffiliated researchers need to photocopy each article in the journal to cover the increased cost.

\section{A map of information production strategies}

It is possible to outline a series of ideal-type strategies based on different combinations of the ways in which the benefits of information production can be appropriated and the cost of inputs minimized. Inputs can be obtained below market price from the public domain, from intrafirm sources, or through sharing/barter with others. Benefits can be appropriated directly or indirectly. Indirect appropriation strategies can be divided between those that rely on market returns affected indirectly by the information production and those that rely on appropriation through non-market mechanisms. Table 1 maps nine ideal type strategies characterized by

Table 1

Ideal-type information production strategies

\begin{tabular}{llll}
\hline $\begin{array}{l}\text { Cost minimization/ } \\
\text { benefit maximization }\end{array}$ & Public domain & Intra-firm & Barter/sharing \\
\hline Direct & Romantic maximizers & Mickey & $\begin{array}{l}\text { RCA (patent-based sales } \\
\text { w/cross-licensing and } \\
\text { patent pools) }\end{array}$ \\
$\begin{array}{l}\text { Indirect } \\
\text { Market }\end{array}$ & $\begin{array}{l}\text { Scholarly lawyers (lawyers/ } \\
\text { doctors who write in journals } \\
\text { to attract clients) }\end{array}$ & $\begin{array}{l}\text { Know-how (law firm } \\
\text { corporate forms; } \\
\text { industrial know-how) }\end{array}$ & $\begin{array}{l}\text { Learning networks } \\
\text { (informal sharing; } \\
\text { defensive patent } \\
\text { portfolios) } \\
\text { Being There (circulating } \\
\text { drafts, workshops) }\end{array}$ \\
\hline
\end{tabular}


these components. All strategies can seek inputs from the market at market price, as well as from the public domain at marginal cost. I do not assume that they solely use their identifying source of inputs or that they do not mix strategies.

I begin with the strategy assumed in most welfare economics models to be the usual appropriation strategy. Appropriation is achieved through assertion of rights, either by selling permission to use the information these organizations produce, or by excluding competitors in reliance on the legal monopoly that the right grants, or both. ${ }^{45}$ These organizations do not own an inventory of intellectual property rights. They include organizations that sell a single software product or a patented gadget, as well as authors selling publication or movie rights or independent code writers who sell to a larger software company. Because they describe the traditional conception of an author laboring in expectation of royalties, I call this strategy "the romantic maximizer." Their sole source of marginal cost inputs is the public domain.

The second strategy similarly sells information outputs, but minimizes costs by vertically integrating sale and management of an inventory of information products with production of new information. Disney or Time-Warner would be examples. The coarsest version of this strategy might be found if Disney were to produce a "winter sports" $30 \mathrm{~min}$ television program by repackaging scenes from existing cartoons, say, one in which Goofey plays hockey followed by a snippet of Donald ice skating. More subtle, and representative of the type of reuse relevant to the analysis here, would be the case where Disney buys the rights to Winnie-the-Pooh, and after producing an animated version of stories from the original books continues to work with the same characters and relationships to create a new film, say, "Winnie-the-PoohFrankenpooh" (or Beauty and the Beast-Enchanted Christmas; or The Little MermaidStormy the Wild Seahorse). ${ }^{46}$ I call this strategy "Mickey." Its adherents have the advantage over other strategies that they have a higher likelihood of finding usable inputs from intrafirm sources at marginal cost when public domain sources dry up. They likely incur some transaction costs not shared by romantic maximizers - inventory administration cost—which dissuade at least some romantic maximizers from developing towards a Mickey model. ${ }^{47}$

The third strategy also relies on direct appropriation, but uses barter to reduce input costs. The cross-licensing and market-sharing agreements among the radio patents holders in 19201921 are a perfect example. ${ }^{48}$ RCA, GE, and AT\&T held blocking patents that prevented each other and Westinghouse from manufacturing the best radios possible given technology at that time. The three companies entered an agreement to combine their patents and divide the radio equipment and services markets in 1920. Westinghouse joined the pool in 1921, adding its own patents, which increased the effectiveness of home receivers. Throughout the 1920s this group pursued direct appropriation by using enforcement actions to exclude competitors from the radio equipment markets, seeking precisely the post-innovation monopoly rents that patent law is designed to grant.

The remaining strategies rely on indirect appropriation of benefits. This does not mean that producers have no property rights in their information products. It simply means that their production strategy does not depend on assertion of rights, and that they can forgo the expense of enforcing rights without affecting their sustainability.

The fourth strategy relies on a positive correlation between availability to others of the information an organization produces and demand for other products it produces. Doctors or lawyers who publish in trade journals are an instance of this strategy. Hence, "the studious 
lawyer." This is the model of appropriation heralded a few years ago by Esther Dyson ${ }^{49}$ and John Perry Barlow ${ }^{50}$ as the future of content production in the digitally networked environment. IBM's participation in free software development of Linux and Apache is also an example, because widespread use of these free software programs increases demand for its hardware and services.

The fifth and sixth strategies are two aspects of supply-side effects of information production, and seem to be common strategies for industrial R\&D outside of drug companies. ${ }^{51}$ Like scholarly lawyers, these organizations rely on indirect appropriation from market sources based on a positive correlation with their own information production, but the positive effect relies on the supply-side advantages they gain from their own access to the information, rather than on the demand-side effects of its wide dissemination. These could be firm-specific advantages, like production know-how, which permit the firm to produce more efficiently than competitors and sell better or cheaper competing products. ${ }^{52}$ The information produced is available at marginal cost for intrafirm use, and its benefits are appropriated using indirect market effects. I call this strategy "know-how" to note Arrow's suggestion that a good deal of information is produced by this mechanism. ${ }^{53}$ Lawyers will be familiar with the advantages law firms obtain from well developed forms to speed up and maintain the quality of common tasks.

Like the know-how strategy, the sixth strategy relies on indirect supply-side market-based benefits of information production. The distinguishing feature of this strategy is that it minimizes costs by sharing information with similar organizations to capture economies of scale, or with organizations in different industries similarly invested in information production, to capture economies of scope. ${ }^{54}$ Like know-how organizations, and unlike Mickeys, RCAs or romantic maximizers, these organizations do not directly sell information or assert rights to exclude competitors. They use early access to the information, gained by their investment in information production, to collect above-normal profits available to those who have early access to the information. This can be done by increasing production efficiency relative to competitors while keeping the information secret, or by participating in an oligopolistic pool, entry into which is reserved for those who have sufficient information production capacity to "pay" for participation. Participants might barter their information for access, or simply be part of a small group of organizations with enough knowledge to exploit the information generated and informally shared by all participants in this "learning network." 55 Rents are obtained from the concentrated market structure, not from assertion of property rights, ${ }^{56}$ which is what distinguishes this strategy from the RCA strategy. While these organizations may not sell patents or assert them to appropriate the benefits, they nonetheless must engage in defensive patent portfolio development so that they have chips to bargain with and defend against defection by other participants who later try to use patents to control information originally shared. ${ }^{57}$ While this strategy is usually described in the patent context, it is not limited to industrial R\&D. Newspapers that use cooperative news agencies and rely on timeliness and accuracy of reporting rather than long-term control of copyrights are also an example of this strategy.

The remaining strategies describe a series of producers who rely on non-market institutions to obtain the benefits of their production, necessarily indirectly. The seventh strategy lumps together what is in fact a diverse category of non-market actors. They include universities and other research institutes; government research labs that publicize their work or the 
Census Bureau; individual academics; authors and artists playing to "immortality"; as well as a host of amateur endeavors, ranging from contributors to the op-ed page, to amateur choirs, to participants in a mailing list or a web-based discussion forum. I call this strategy "Joe Einstein" (to include the range from Joe Public amateur producer to the most highly professional non-commercial producers). This is the strategy used to produce most basic science and political argument (political parties and civic advocacy groups are Joe Einstein organizations), among other important information goods. Joe Einsteins minimize input costs by obtaining information inputs from the public domain. They make information outputs freely available, either by placing them in the public domain-most obviously when publishing patentable innovations without seeking a patent—or by refraining from enforcing proprietary claims, or by specifically and publicly licensing all to use and transform their materials - as is the case with free software distributed under the General Public License. They appropriate the benefits of their investment, if at all, through reputational gains, research grants, charitable contributions, teaching positions rationed by publication-based reputation, or from desired behavioral adaptations by their audiences (political and religious organizations are the obvious instance of the latter). Amateurs cross-subsidize their information production with revenues unrelated to the information production function they fulfill. Some production in this model may occur with no expectation of appropriation, as a reflection of the producer's taste for creativity.

The eighth and ninth strategies describe either temporary or partial departures of "Joe Einstein" organizations from the output-management strategy of publicizing the information and making it available in the public domain. The strategy I call "Manhattan Project," as suggested by its name, refers to non-market producers that rely heavily on their own information products as inputs into their own production, and do not make that information widely available because their non-market function requires that the information not be disseminated. In other words, production is financed by non-market sources that are interested in acquiring the information but limiting access to it. The strategy I call "Being There" is more temporary, and relates to the time delay some non-market producers can use to gain relative advantage later on, when they switch to the Joe Einstein strategy. Releasing a draft paper to a limited set of colleagues to get comments and improve it before publication would be an obvious example. ${ }^{58}$ This activity parallels in the non-market arena the information sharing pools whose participants share information to gain advantages in their correlated markets.

\section{Normatively-sensitive effects of changes in intellectual property rules}

The differential effects of increases in intellectual property protection ${ }^{59}$ on divergent strategies suggest that such increases lead to commercialization, concentration, and homogenization of information production. Non-commercial producers will systematically shift to commercial strategies. Small-scale producers will systematically be bought up by large-scale organizations that integrate inventory management with new production. And inventory owners will systematically misallocate human creativity to reworking owned-inventory rather than to utilizing the best information inputs available to produce the best new information product. These effects are the result of the differential effects of increased protection on the costs and benefits of various strategies. 
First, by definition, only firms that rely on direct appropriation-appropriation based on legal rights to exclude - can benefit from an increase in intellectual property. Indirect appropriation strategies do not benefit from an increase in protection because they appropriate the value of their efforts either by releasing the information for public domain use or by relying on secrecy, not property rights.

Second, all strategies suffer some increase in their input costs, because of an increase in the probability that an input they need in their productive activities will be owned by another firm. Strategies that rely on the public domain as their primary source of marginal cost inputs-Joe Einsteins, scholarly lawyers, and romantic maximizers - will suffer the greatest cost increase. Organizations that minimize costs by utilizing intrafirm sources of information suffer the least increase in costs, because access to their owned inventory continues to be at marginal cost, regardless how extensive their power to exclude others from it. Organizations that rely on barter may be forced to engage in more aggressive rights acquisition, because an increase in excludability increases the probability that their utilization of a collaborator's information could provide grounds for a strategic suit. This increases the cost of using barter/sharing systems, but not the appropriability of its outputs. ${ }^{60}$

As among the strategies that benefit from increases in rights, romantic maximizers are more likely to suffer net losses from an increase in rights than either Mickeys or RCAs. The biggest winners are Mickeys. They not only benefit from the increase and mitigate costs by reutilizing inventory, but also gain a distributive windfall on inventory they own at the time of the change in law. A 20-year extension in the duration of copyright gives Disney 20 more years of selling The Mouse after production costs have already been sunk. The higher probability of cheaper future production and the prospect of windfalls on existing inventories should also make investment in inventory-the distinguishing characteristic of Mickeys-more attractive ex ante.

Based on these effects, we would expect to see creative individuals and information inputs reorganized to respond to the relative costs and benefits associated with the new level of property rights protection. More of these factors of information production will likely be employed using direct appropriation strategies, and fewer would be used to produce for indirect appropriation. This is the "commercialization" entailed by strong property rights-more of those who produce information will produce on a model that seeks commercial appropriation through assertion of rights.

Furthermore, Mickeys are likely to expand more rapidly than the other direct appropriation strategies, and are likely to hire former Joe Einstein producers and some romantic maximizers (both for talent and inventory). We would expect consolidation of Mickey organizations in order to gain the economies of scope created by internalizing large and diverse inventories of information inputs and human capital pools. This is the "concentration" effect of strong intellectual property rights.

Finally, the primary beneficiaries of increased intellectual property rights-Mickey organizations - are likely to misallocate resources for information production. One feature that differentiates Mickey from other strategies is that it involves purposeful application of human capital to a set of information inputs defined by their ownership. Disney employees work with Mickey and Goofy, Warner Bros. employees work with Bugs and Daffy. Mickey organizations are therefore likely to misallocate human capital to work with owned-inventory 
even if work with information owned by others would be more productive. This is because they can use their own inventory at marginal cost, but must pay above marginal cost to the owner of purchased information inputs. Their private cost for using each input is different, although the social cost is the same.

Imagine that a firm can produce product $x$ with information inputs from its inventory, $I_{\text {intrafirm }}$ at marginal cost of zero, plus human capital costs; or product $y$ with information inputs purchased at an above-marginal cost positive price $C_{\mathrm{m}}$, plus human capital costs. The social cost of its use of information is zero irrespective whether it uses information from its inventory or from purchased inputs. The firm will produce $x$ rather than $y$, so long as the price the firm can charge for $x, P_{x}$, is greater than the price the firm can charge for product $y$, $P_{y}$, minus the difference between the price of the purchased information input and its social cost, $C_{\mathrm{m}}-0=C_{\mathrm{m}}$. For the range $P_{x}+C_{\mathrm{m}}>P_{y}>P_{x}$, Mickey firms acting rationally will misallocate human capital, assuming $P_{y}$ and $P_{x}$ similarly represent the social value of the product whose value they capture for the seller. As the cost of market-purchased inputs $\left(C_{\mathrm{m}}\right)$ increases because of increases in intellectual property rights this range will grow and the misallocation will increase. This is the homogenization effect of intellectual property rights. It relates to inefficient application of creative talent to existing information inputs, and is independent of any laments regarding the homogenization effects of large-scale commercial mass media.

It is important to note that the behavioral adaptations outlined arise from the decline in availability of information for use at marginal cost in new production, not as a response to an increase in transaction costs that accompanies expansion of rights. Even if information were licensed through a mechanism that eliminated transaction costs altogether, it would still be licensed at a price above marginal cost, because suppliers that license their information products must see a positive supply price. Any organization that previously obtained information inputs from the public domain at marginal cost will see an increase in cost if those inputs become subject to licensing. Similarly, any organization choosing between an information input available from its owned inventory and an information input that must be licensed will see a price equal to marginal cost for inputs from its own inventory, and an above-marginal cost price for external inputs. The presence or absence of sophisticated licensing mechanisms, whether technological or through collective rights organizations, ${ }^{61}$ will affect the magnitude, but not direction, of the effects of increases in property rights on the payoffs to the strategies described here.

\section{Feedback effects}

Organizational adaptations to an expansion of intellectual property protection will likely have feedback effects that amplify the direction and speed of the shift in strategies, and lock them in institutionally. First, a larger ratio of new information will be owned, further decreasing the availability of pertinent public domain materials. Second, more investments will be made in effecting additional institutional changes that make ownership of inventory and integration of new production with inventory management more profitable. Third, more investments will be made in producing demand for information of the type produced for sale and by reuse 
of owned inventories. And fourth, organizations that expect these developments will shift to strategies that fare better under increasing protection conditions.

\subsection{Increased cost of newly minted information inputs}

It is likely that newly minted information is not perfectly substitutable for old information. This will be particularly pronounced in sectors dependent on incremental progress, as in software development, as well as in fashion-sensitive products where taste changes rapidly. Access to fresh information is therefore likely to be an independent sub-category within the mix of information inputs an organization needs to engage in new production. An increase in the proportion of new information that is produced by Mickeys and romantic maximizers, who produce owned information, and a decrease in the proportion of information produced by Joe Einsteins or studious lawyers, who produce openly available information, will cause a larger portion of the sub-category of new information produced after an expansion of property rights to be owned. This increase in the proportion of owned information increases the probability that, after the change, information that producers need as input will be enclosed, rather than in the public domain. This effect mimics and amplifies the effects of the initial increase in intellectual property protection. The analysis follows.

An organization seeking information inputs will see the world as composed of two lots of information inputs, old information $I^{\mathrm{o}}$ and new information, $I^{\mathrm{m}}$. To represent this, assume that the organization needs to pick one input out of each lot. Assume that each of $I^{\mathrm{O}}$ and $I^{\mathrm{m}}$ is comprised, like $I$, of $I_{\mathrm{pd}}+\left[I_{\text {intrafirm }}+I_{\mathrm{m}}+I_{\mathrm{b}}\right]$. At $T_{0}, I^{\mathrm{o}}$ and $I^{\mathrm{m}}$ are comprised of identical ratios of $I_{\mathrm{pd}}$ to $\left[I_{\text {intrafirm }}+I_{\mathrm{m}}+I_{\mathrm{b}}\right]$, say $1: 1$. To simplify, ignore $I_{b}$ and assume that of all owned information, an organization with a large inventory sees $10 \%$ as $I_{\text {intrafirm }}$ and $90 \%$ as $I_{\mathrm{m}}$, while a small organization sees $100 \%$ as $I_{\mathrm{m}}$. We can see the effects in a simple arithmetic example, by assuming that the cost of a new input from $I_{\mathrm{pd}}$ or $I_{\text {intrafirm }}$ is 0 and the cost of a new input from $I_{\mathrm{m}}$ is 1 . At $T_{0}$ the expected cost of inputs for a small organization is $[(0.5 \times 0)+(0.5 \times 1)] \times 2=1$, representing the equal probability that an input will be available at a cost of 0 from the public domain or at a cost of 1 from market sources, which is equal as to each lot from which the producer must pull an input. For an organization with a large inventory, the expected cost is $[(0.5 \times 0)+(0.05 \times 0)+0.45 \times 1] \times 2=0.9$. In other words, for such an organization there is a small probability that an owned input will be available from its own inventory at 0 , rather than from market sources at 1 , and this is equally so for both lots.

At $T_{1}$ a new law is passed, that increases intellectual property protection. Section 5 suggests that at the margin slightly less information produced after $T_{1}$ will be produced by Joe Einsteins or studious lawyers, and slightly more will be produced by romantic maximizers, RCAs, and Mickeys. The latter organizations all produce information that is owned, and hence is one of $I_{\text {intrafirm }}, I_{\mathrm{m}}$, or $I_{\mathrm{b}}$. The former organizations produce information that is all part of $I_{\mathrm{pd}}$. We would represent this shift by suggesting that at a later time, $T_{2}$, a producer facing the universe of information inputs will continue to see a ratio of $1: 1$ for $I_{\mathrm{pd}}^{\mathrm{o}}$ relative to $I_{\text {intrafirm }}^{\mathrm{o}}, I_{\mathrm{m}}^{\mathrm{o}}$, and $I_{\mathrm{b}}^{\mathrm{o}}, 62$ but will see another ratio, say, $1: 1.5$, of $I_{\mathrm{pd}}^{\mathrm{n}}$ relative to $I_{\text {intrafirm }}^{\mathrm{n}}, I_{\mathrm{m}}^{\mathrm{n}}$, and $I_{\mathrm{b}}^{\mathrm{n}}$. Again, we can ignore $I_{\mathrm{b}}$, and we can see that an organization with no inventory will see an expected input cost of $[(0.5 \times 0)+(0.5 \times 1)]+[(0.4 \times 0)+(0.6 \times 1)]=1.1$. Since it must pick one input from 
the new information lot, and since the expected price of inputs from that lot has increased, the producer will see an increase in expected costs. It is important to note that this increase is cumulative to the increase that caused the initial change in payoffs, and is not caused by an additional increase in legal protection. It is the adaptation of organizations to the initial legal change by adopting more direct-appropriation based strategies and decreasing production for the public domain that increases the expected cost of new inputs, and hence the expected cost of information production generally. As with the original effect of the increase in rights, the feedback effect exists, but is muted for organizations with large inventories, because of the probability that inputs will be available from $I_{\text {intrafirm }}:[(0.5 \times 0)+(0.05 \times 0)+0.45 \times 1]+$ $[(0.4 \times 0)+(0.06 \times 0)+(0.54 \times 1)]=0.99$.

As with the original change in payoffs, the negative feedback effect of an increase in property rights occurs at a slower pace for organizations with large inventories. This would lead one to expect increasing adoption of Mickey strategies as other strategies become unsustainable while Mickey persists.

\subsection{Political economic feedbacks}

Given the effects of institutional change on the returns to different organizational strategies, rational organizations will invest in sustaining favorable institutional arrangements. They will attempt to pass new institutional changes that increase the payoffs to their chosen organizational strategy and resist changes that reduce those benefits. Eisenberg describes how after universities were given the right to appropriate government-funded research by the Bayh-Dole Act they became a new constituency that actively opposed adjustment of the policy when its detrimental effects became clear. ${ }^{63}$ Samuelson describes the battle over the Digital Millenium Copyright Act as one that pitted Hollywood, the quintessential Mickey, against Silicon Valley, which appears to rely heavily on know-how, studious lawyer, and Joe Einstein strategies. ${ }^{64}$ Increased activity by certain types of organizations will increase investment in attaining institutional arrangements that support the strategy utilized by those organizations. Assuming that lobbying works, this increases the probability that future institutional changes will reinforce the direction of the path chosen in the first institutional choice. ${ }^{65}$

\subsection{Feedback effects on taste}

Organizations invest in creating demand for their products. Although the common practice is to treat preferences as exogenous, one need not blind oneself to the revealed behavior of commercial organizations - they invest heavily in producing preferences for their products. ${ }^{66}$ After all, one must give Madison Avenue its due. ${ }^{67}$ One might imagine, for example, Mickey organizations investing in creating a taste for familiar aspects of their owned inventory, in order to increase the value of reused inventory. ${ }^{68}$ Differential investment in preference formation creates a positive feedback effect. It increases demand for products produced by organizations utilizing more prevalent strategies and decreases demand for products produced with less common strategies. Assuming that all organizations are equally successful at creating demand for their products, increased prevalence of Mickeys should lead to increased investment in forming preferences for their products. This should increase relative demand for their 
products. Repackaging the Mouse becomes not only cost effective, but also responsive to demand.

\subsection{Effects of expectations regarding what other organizations will do}

Finally, in dynamic systems rational actors adjust their behavior based on their expectations about the behavior of others, rather than on static conditions at the time of the decision. ${ }^{69}$ Organizations will adopt a strategy based on their expectations of the choices of other organizations, and their predictions of the institutional choices to be made through the political process. Expectations that Mickeys will occupy an ever-increasing portion of the information production environment will likely lead organizations to invest in protectible materials and to shift to Mickey, RCA, or romantic maximizer strategies sooner than might be warranted by a static assessment of market conditions immediately following an increase in property rights. Moreover, expectations regarding the dynamic effects on institutional development will create particularly intense incentives to adopt a Mickey strategy, not only to gain higher returns to new production, but also to obtain transition windfalls from future increases in intellectual property rights.

\section{Policy implications}

The analysis offered here has two primary policy implications. First, intellectual property rights will systematically yield less of their desired aggregate effects than usually predicted by models that do not include the divergent effects on different business strategies. Second, strong intellectual property rights tend to lead towards commercialization and concentration of information production, and to a certain type of homogenization. Whether these effects are desirable, and if not, whether they are worth any given quantitative increase in outputs expected from an increase in protection is a normative question that cannot be resolved within economic analysis.

Welfare economic models of the effects of intellectual property on information productionregardless their specific flavor-usually treat information producers as being affected in roughly equal ways by changes in law. Whenever this simplifying assumption is used, it systematically biases the analysis in favor of property rights, since some information producers only bear the costs of an increase, but gain none of its benefits. For future studies, this suggests that fruitful work could be done in analyzing at an industry-specific level the differential impact of specific intellectual property rules on different players in different industries, based on the specific makeup of these industries and the salience of existing information inputs relative to other resources to the cost of production in it. Political economy could valuably trace these effects to the positions that various players take in the legislation of intellectual property rights.

Moreover, feedback effects I describe suggest that the adverse effects of property rights in information predicted by the Arrow/Nordhaus line of economic analysis will occur more rapidly than predicted by that model, and that these adverse effects may be difficult to reverse. Any specific proposed legal change that in principle would optimize production in a static 
analysis for the time period immediately following the change will begin a dynamic process whose end point may be beyond the theoretically optimal level of protection. Because amplification occurs through organizational adaptations and entails political entrenchment, the process begun by a change in law may be path determining, and may lock an economy into sub-optimal arrangements indefinitely.

Equally important is the observation that decisions about the level of intellectual property protection have an irreducible normative component. The model I present here suggests that any given level of aggregate production might, in principle, be achievable through different mixes in production strategies. Increases or decreases in intellectual property rights affect the mix of strategies used for information production, even if they have no aggregate effects. Specifically, strong protection leads to commercialization, concentration, and homogenization of information production.

Choices regarding the mix of strategies a society uses to produce information, knowledge, and culture, are political. Different people in a society are likely to have different normative commitments about how, aggregate effects aside, information should be produced in a society. One might imagine an argument that having information in society produced by organizations and individuals responsible solely to market signals is preferable to having information produced by organizations that must rely on government funding or on elitist systems of reputation and prestigious appointments. One might equally imagine an argument that having more of our information environment produced by academics who need not satisfy anyone's taste but their own sense of what is true and good, and amateurs, the yeoman farmers of the information environment, is preferable to having more of that environment produced by Michael Eisner or Ruppert Murdoch.

My point here is not to argue the benefits of one strategy or another. The point is that once one recognizes that intellectual property rules affect how our society produces information and who is likely to be an effective producer, not only how much information our economy produces, choices with respect to intellectual property rules become irreducibly normative, or political. And this normative choice cannot be resolved by reference to economics. This effect is particularly important given the enormous empirical difficulty of predicting the aggregate effects of any given proposed change in intellectual property ${ }^{70}$ For, when we have no clear prediction as to the aggregate effects of a rule change, we are, as a matter of practical policy making, in the "all things aggregate being equal" rubric. And at least when we are in that rubric, it is indefensible to frame in positive terms a decision that is by and large normative: a choice of what kinds of people and organizations, responding to what kinds of incentives and operating under what types of constraints, will produce our information environment.

\section{Notes}

1. For a compact review of this literature see William W. Fisher III, Theories of Intellectual Property, in New Essays in the Legal and Political Theory of Property, Part III.A. (Stephen R. Munzer, ed., 2000).

2. For a compact review of this literature see F.M. Scherer, Schumpeter and Plausible Capitalism, 30 Journal of Economic Literature 1416-1433 (1992). 
3. See, e.g., Partha Dasgupta and Joseph Stiglitz, Industrial Structure and the Nature of Innovative Activity, 90 Economic Journal 266-293 (June 1980); Paul Romer, Endogenous Technological Change, 98(5) Journal of Political Economy, S73 (1990); Glen C. Loury, Market Structure and Innovation, Quarterly Journal of Economics 93 (1979); F.M. Scherer, Nordhaus's Theory of Optimal Patent Life: A Geometric Reinterpretation, 62 Am. Econ. Rev. 422-427 (1972). In this literature I would include those studies that look at firm cooperation and networking, rather than property rights, to foster innovation. See Wesley M. Cohen and Daniel A. Leventhal, Innovation and Learning: The Two Faces of R\&D, 99 The Economic J. 569-596 (1989); Walter W. Powell, Kenneth W. Koput, Laurel Smith-Doerr, Interorganizational Collaboration and the Locus of Innovation: Networks of Learning in Biotechnology, 41 Administrative Science $Q$. 116-145 (1996).

4. Kenneth J. Arrow, Economic Welfare and the Allocation of Resources for Invention, in The Rate and Direction of Inventive Activity: Economic and Social Factors 609 (National Bureau of Economic Research, 1962).

5. William D. Nordhaus, Invention, Growth, and Welfare: A Theoretical Treatment of Technological Change (1969).

6. Examples of this literature include Pankaj Tandon, "Optimal Patents with Compulsory Licensing," 90 Journal of Political Economy, 472-486 (1982); Richard Gilbert and Carl Shapiro, "Optimal Patent Protection and Breadth," 21 Rand Journal of Economics 106-112 (1990); Paul Klemperer, "How Broad Should the Scope of Patent Protection Be?," 21 Rand Journal of Economics 113-130 (1990); William M. Landes \& Richard A. Posner, An Economic Analysis of Copyright Law, 18 J. Legal Stud. 325 (1989), William Fisher, "Reconstructing the Fair Use of Doctrine," 101 Harvard Law Review 1661-1795 (1988), and more recently, Steven Shavell \& Tanguy van Ypersele, Rewards versus Intellectual Property Rights, NBER Working Paper No. 6956 (February 1999).

7. See Suzanne Scotchmer, Standing on the Shoulders of Giants: Cumulative Research and the Patent Law, 5 J. of Economic Perspectives 29-41 (1991). Arrow, supra, at 618 .

8. Harold Demsetz, Information and Efficiency: Another Viewpoint, 12 Journal of Law \& Ec. 1 (1969). See, e.g., Paul Goldstein, Copyright's Highway, From Gutenberg to the Celestial Jukebox 178-179 (1994).

9. See Frank H. Easterbrook, Cyberspace vs. Property Law? 4 Tex. Rev. L. \& Pol. 103 (1999); Robert P. Merges, The End of Friction? Property Rights and Contract in the “Newtonian” World of On-Line Commerce, 12 Berkeley Tech. L. J. 115 (1997); Robert P. Merges, Contracting into Liability Rules: Intellectual Property Rights and Collective Rights Organizations, 84 Cal. L. Rev. 1293 (1996).

10. See Wendy J. Gordon, An Inquiry into the Merits of Copyright: The Challenges of Consistency, Consent, and Encouragement Theory, 41 Stanford Law Review 1343 (1989); Robert P. Merges, Are You Making Fun of Me?: Notes on Market Failure and the Parody Defense in Copyright, 21 AIPLA Q. J. 305 (1993).

11. Fisher provides an extensive bibliography of work in this vein, see Fisher, Theories of Intellectual Property, supra. 
12. See Wesley M. Cohen, Richard R. Nelson, \& John P. Walsh, Protecting Their Intellectual Assets: Appropriability Conditions and Why U.S. Manufacturing Firms Patent (or Not), NBER Working Paper No. 7552 (February 2000); Bronwyn H. Hall and Rose Marie Ham, The Patent Paradox Revisited: Determinants of Patenting in the US Semiconductor Industry 1980-1994, NBER Working Paper 7062 (March 1999); Richard C. Levin, Alvin K. Klevorick, Richard. R. Nelson, Sidney G. Winter, Appropriating the Returns from Industrial Research and Development 3 Brookings Papers on Economic Activity 783, 794-96 (1987); and Edwin Mansfield, Mark Schwartz, and Samuel Wagner, Imitation Costs and Patents: An Empirical Study, 91 The Economic Journal 907-918 (December 1981).

13. See Romer, Endogenous Technological Change, at S73-S74. Every economic good can be defined by the degree to which it is excludable, and the degree to which it is rival. A good is excludable to the extent that its producer can appropriate its benefits by excluding those who benefit from it unless they pay a price. A good is rival to the extent that its use by one person prevents (rivals) its use by another person. The former is a function of the available technology for exclusion, and the institutional (legal) framework that permits or facilitates such technically feasible exclusion. The latter is purely "technological." It is an attribute of the good itself that either can or cannot, as a practical matter, be used by many people without degradation or rivalry. A pure private good is one that is excludable and rival. A pure public good is one that is non-excludable and non-rival. When a good is public in the sense of being non-excludable, it is so because no firm can capture the social value of its provision. It must therefore be provided publicly, if at all. By definition, a non-rival good is one that can be used by one person without preventing or degrading its use by any other person. Any additional person who uses the good imposes no social cost. Its optimal demand price is therefore zero. At that price, it would not be produced by private interests, and must be provided publicly. At a higher price that would induce private production, it will be under-utilized relative to the optimal level of utilization.

14. "Information is not only the product of inventive activity, it is also an input-in some sense, the major input apart from the talent of the inventor." Arrow, supra, at 618.

15. See The Netcraft Web Server Survey, http://www.netcraft.com/Survey/

16. See http://www.li.org. The operating system is more commonly called simply "Linux", after its kernel, but the whole project integrates large chunks that were developed as part of the GNU project, pioneered by Richard Stallman in the mid 1980s.

17. The description here relies mostly on two widely recognized descriptions of open source strategy, its relative advantages, and what makes it tick, Eric Raymond, The Cathedral and the Bazzar (1998) http://www.tuxedo.org/ esr/writings/cathedral-bazaar/, and Eric Raymond, Homesteading the Noosphere (1998) http://www.tuxedo.org/ esr/writings/ homesteading/homesteading.html. See also Josh Lerner \& Jean Tirole, The Simple Economics of Open Source, NBER working paper No. 7600 (March 2000); Eben Moglen, Anarchism Triumphant: Free Software and the Death of Copyright, First Monday, August 1999, available http://emoglen.law.columbia.edu/my_pubs/anarchism.html

18. I rely on the Definition of Open Source http://www.opensource.org/osd.html

19. http://www.opensource.org/halloween/halloween1.html 
20. See discussion of decommoditizing protocols in the annotated Halloween document, http://www.opensource.org/halloween/halloween1.html\#decommoditize

21. Rebecca S. Eisenberg, Intellectual Property at the Public-Private Divide: The Case of Large-Scale cDNA Sequencing, 3 U. Chi. L. Sch. Roundtable 557 (1996).

22. See Eisenberg, cDNA Sequencing, at 565-566, describing a collaboration between Human Genome Sciences, which develops sequences, and SmithKline Beecham, which would produce therapeutic and diagnostic products therefrom, and the Incyte Pharmaceuticals' database, LifeSeqk, which is intended to by licensed on a non-exclusive basis to multiple firms for development into products.

23. Merck \& Co. has funded a human cDNA sequencing project at the Genome Sequencing Center at Washington University to create a public-domain resource. Id.

24. Id., at 570-571.

25. Most expressly, this can be seen in the Extended Guide for Authors of Nature, which states "Papers reporting protein or DNA sequences ... will not be accepted without a Genbank ... accession number." See, e.g., Nature Extended Guide to Authors, Section 5.3, available http://www.nature.com/Nature2/serve?SID $=18717415 \& \mathrm{CAT}=\mathrm{NatGen} \&$ $\mathrm{PG}=\mathrm{g} 2 \mathrm{a} / \mathrm{g} 2 \mathrm{a} . \mathrm{html} \#$ 5. See also Science, Conditions of Acceptance ("Archival data sets (such as sequence and structural data) should be deposited with the appropriate data bank and the identifier code should be sent to Science for inclusion in the published manuscript (coordinates should be released no later than 1 year after publication)"), available http://www.sciencemag.org/misc/con-info.shtml\#conditions; Cell, ("Publication of a research article in Cell is taken to imply that the authors are prepared to distribute freely to academic researchers for their own use any materials (e.g., cells, DNA, antibodies) used in the published experiments. In cases of dispute, authors may be required to make primary data available to the Editor. Nucleic acid and protein sequences as well as X-ray crystallographic coordinates should be deposited in the appropriate database"), available http://www.cell.com/misc/itoa.shtml. GenBank is the $\mathrm{NIH}$ public domain depository for DNA sequences. See http://www.ncbi.nlm.nih.gov/ genbank

26. In other words, I do not rely on claims about bounded rationality, or lack of information, or incommensurability between the motives of non-commercial and commercial producers.

27. By human capital I mean creative effort. Romer defines human capital as acquired educational capabilities. This is useful when focusing on industrial or scientific innovation, and may make analysis more easily quantifiable, but the element that human capital "gets at" is creativity, as distinguished from the application of work, money, or existing information to a productive enterprise.

28. Romer, at S74; Arrow, at 618 (two most important inputs are creative talent and existing information).

29. Throughout this paper I use a slightly unorthodox definition of the public domain, as the range of information uses privileged to all absent particularized facts that prohibit a particular use by a particular person. For a defense of this definition as more useful than the doctrinal definition for analyzing social consequences of changes in intellectual property law see Yochai Benkler, Free As the Air to Common Use: First 
Amendment Constraints on Enclosure of the Public Domain 74 N.Y.U. L. Rev. 354 (1999). The validity of the analysis in this paper in no way depends on whether one adopts my definition or the more conventional definition.

30. One might imagine activities that require more or less creativity, while nonetheless being creative enough to justify protection. Say, the difference between writing a sonnet and writing a news report about a specific event. To the extent, in other words, that a productive activity has a very high $C_{\mathrm{h}}$ value, the implications of the analysis that follows are attenuated.

31. Obviously, one response to increases in $C_{\mathrm{i}}$ is to lower the ratio of the quantities of information inputs to human capital by using more creative talent, although then presumably the price of human capital would rise, increasing $C$ in an indirect, rather than direct, response to the increase in $C_{\mathrm{i}}$.

32. The market price must at least cover suppliers' production costs and is therefore a positive price. The marginal cost, as explained earlier, of information, is zero, reflecting that information is a non-rival good.

33. The value of $C_{\mathrm{b}}$ will likely be higher than that of $C_{\mathrm{m}}$, however, because firms will likely "insure" against defection by firms with which they cooperate and share information. They could do this by, for example, investing in defining and protecting intellectual property rights in their own information products, not because they plan to sell them, but in order to have a credible threat of retaliation when the other party defects, or they might design their products with redundancy, in order to avoid over-dependence on a single cooperative player. The cost of this insurance will presumably be less than the difference between $C_{\mathrm{b}}$ and $C_{\mathrm{m}}$, otherwise the firm would buy a license rather than rely on cooperation. Use of shared information inputs will nonetheless be more expensive than use of a firm's owned or public domain inputs.

34. Note that, unlike the information inputs themselves, the communication of information is a rival good-trees for pulp, copper for wires, and attention for reading are all resources for which there are rival uses.

35. A criticism of this assumption is that "commercial" users will likely require more access to commercially produced information, and non-commercial producers are likely to exchange information within the group of similarly motivated producers. If this were true, the implications of the heterogeneity in information production strategies would be much diminished. While this is essentially an empirical question, I think it plausible to assume that, for example, a political satirist needs access to popular iconography, including trademarked icons, whether she sells the rights to put her cartoons on mugs or publishes for free in a non-profit political medium. Similarly, a person who writes a spreadsheet for Linux needs to provide backward compatibility and user-interchangeability with the dominant spreadsheet program no less than does a commercial company writing a new spreadsheet and trying to enter a market dominated by another spreadsheet. See Lotus v. Borland 49 F.3d 807 (1995).

36. This does not mean that the firm will always choose the "best" input. It only means that a firm will be willing to pay a positive price for an owned input if it expects to be able to use that input to produce a product whose value is greater, by more than the cost 
of the owned input, than that of the best product it could produce using any unowned input available to it at zero cost. Since I assume that the firm seeks to maximize net benefits, it will choose the input that maximizes its net gains given its cost relative to its estimated utility as input.

37. If, as is more likely, the cost of communicating information while retaining its excludability is higher than the cost of communicating it without similarly assuring its downstream excludability, then one must treat $C_{\text {comm }}$ as an incremental component of each of $C_{\mathrm{m}}$ and $C_{\mathrm{m}}$, which is larger for $C_{\mathrm{m}}$ than for $C_{\mathrm{m}}$. This would simply increase the cost differential between $C_{\mathrm{m}}$ and $C_{\mathrm{m}}$, and therefore amplify the effect of an increase of property rights protection on information input costs.

38. In this paper I do not attempt to differentiate between specific different rules, which may have different effects on various strategies. An obvious next step in the analysis, which I leave for another paper, will be to examine specific rules to see how their effects are likely to deviate from the effects of a generic, analytically defined "increase in protection," which refers to an across the board increase in legal excludability of information outputs-like a generally-applicable term extension.

39. This definition is backed out of the technologically/legally-determined element of what makes something an economic good-“excludability." It is the appropriate definition because the economic function of property rights is to enhance excludability, and the definition therefore separates for analysis those firms that utilize the excludability created by property rights from those that do not.

40. Because information is non-rival and its optimal demand price at any moment is zero, the extent to which producers can employ indirect appropriation mechanisms is precisely the extent to which production incentives can be attained without the usual sacrifice of inefficient loss of access.

41. Raymond, Cathedral and Bazaar, supra.

42. Elizabeth Eisenstein describes the centrality of print to the revolution in astronomy in the late 15 th and early 16 th century precisely in terms of the reduction in the communication cost of obtaining the works of past astronomers in The Printing Press as an Agent of Change 578-582 (1977).

43. This is an extension of Romer's point that information production in an economy is an increasing returns activity. See Romer, supra, at S94-S95.

44. This is a modification of the facts of American Geophysical Union v. Texaco, 60 F.3d 913 (2nd Cir. 1994) (holding that commercial companies must pay royalties for copies made by their researchers).

45. The focus on rights-based appropriation-through sales or post-innovation legally protected monopolies - is justified because it is the basic assumption that the drive to obtain such rights-based capacity to exclude is what makes intellectual property work.

46. A search under "Disney" of Amazon.com is quite instructive about the range of uses that can be made of this strategy.

47. In the absence of such a cost, it might be more accurate to see all romantic maximizers as Mickeys-in-the-making. But even in the absence of such costs, one could imagine that some producers specialize in highly innovative production and are bad at inventory 
management, while others would be better at managing inventory and recombining inventory items with new productive effort.

48. See Gleason L. Archer, History of Radio to 1926 172-198 (1938); Erik Barnouw, A Tower in Babel: A History of Broadcasting in the United States, Vol. 1, 59, 65, 72-73 (1966).

49. Esther Dyson, Intellectual Value, WIRED 3.07 (1995).

50. John Perry Barlow, The Economy of Ideas, WIRED 2.03 (1993).

51. See Cohen et al., Levin et al.; Mansfield et al.

52. Id. (secrecy, lead time, and learning curve advantages regarded as more effective than patents by most firms). See also F.M. Scherer, Learning by Doing and International Trade in Semiconductors, (faculty research working paper series R94-13, John F. Kennedy School of Government, Harvard University 1994) (empirical study of semiconductor industry suggesting that for industries with steep learning curves investment in information production is driven by advantages of being first down the learning curve rather than the expectation of legal rights of exclusion).

53. Kenneth J. Arrow, The Economic Implications of Learning by Doing, 29 Rev. of Economic Studies 155-173 (1962).

54. Richard R. Nelson, The Simple Economics of Basic Scientific Research, 48 Journal of Political Economy 297-306, 303 (June 1959); Walter W. Powell, Networks of Learning in Biotechnology, Opportunities and Constraints Associated with Relational Contracting in a Knowledge-Intensive Field, in Expanding the Boundaries of Intellectual Property: Innovation Policy for the Knowledge Society (R. Dreyfuss, D. Zimmerman, H. First eds.) 251-266 (Oxford, 2001).

55. The behavior is described in Wesley M. Cohen and Daniel A. Leventhal, Innovation and Learning: The Two Faces of R\&D, 99 The Economic J. 569-596 (1989). The term I borrow from Powell, supra.

56. See, e.g., F.M. Scherer, Nordhaus's Theory of Optimal Patent Life: A Geometric Reinterpretation, 62 Am. Econ. Rev. 422 (1972).

57. On the correlation between increased scope and availability of patents and defensive acquisition of patents see Hall \& Ham, supra.

58. Marshall Van Alstyne pointed out to me that such early release to the relevant community of knowledge also "marks" a statement as belonging to the maker of it. This secures for that person the credit of making the statement, which is the central component of academic appropriation of the benefits of production.

59. By "increase" or "decrease" in protection I mean a change in law that increases or decreases the probability that information products covered by the law will be excludable.

60. Both the Cohen et al. study and the Ham \& Hall study suggest that many firms engage in aggressive rights acquisition defensively, to avoid strategic suits by competitors, rather than to serve their appropriation strategy.

61. Merges is the primary proponent of the position that effects on transaction cost-reducing mechanisms like CROs can justify stronger property rights in information than welfare economics would otherwise prescribe. See e.g., Merges, Contracting into Liability Rules, supra. 
62. The assumption does not fit any case of retroactive application, which is the normal case when the increase in protection is achieved by judicial interpretation, and is often the case in legislation, because legislation often responds to the pressures of those who already own inventories and are seeking the windfall created by retroactive legislation. The assumption is necessary in order to isolate the feedback effect, independent of and cumulative to the direct effect of the increase in protection, which is what would change the ratios of owned to unowned old information. But relaxing the assumption would simply magnify the effect by combining direct and feedback effects into a single analysis.

63. See Rebecca S. Eisenberg, Public Research and Private Development: Patents and Technology Transfer In Government-Sponsored Research, 82 Va. L. Rev. 1663, 1715-1724 (1996).

64. Pamela Samuelson, Intellectual Property and the Digital Economy: Why the AntiCircumvention Regulations Need To Be Revised, 14 Berkeley J. L. \& Tech. 519, 522-523 (1999).

65. Douglass C. North, Institutions, Institutional Change, and Economic Performance (1990).

66. A wonderful description of the emergence of preference-production in the 19th century United States is James Beniger, the Control Revolution 264-278 (1986).

67. The 1992 Economic Census indicates that firms spent at least \$20 billion a year on advertising. 1992 Census of Service Industries (taxable firms)-U.S. Summary Business services, SIC 731. Available http://www.census.gov/epcd/www/sc92h73.html. While some of this expenditure is likely intended to provide information about availability of goods or services to satisfy existing preferences, the primary function is likely preference formation and management.

68. "An enterprise must consider its ability to capture the potential entrepreneurial benefit resulting from any demand it creates .... [A] copyright holder can capture more income by encouraging a desire to watch Mean Streets than from a desire to go for a walk on the mean streets. The Walt Disney Co. benefits more from people enjoying Fantasyland than from their enjoyment in engaging in imaginative fantasies (particularly if their fantasies do not require specific commodified props) .... A firm gains little from creating preferences unless it is in a position to profit from their existence. Thus, the market incentive is to create preferences for monopolized qualities of products rather than generic aspects of life. And there is no incentive to generate desires (or capacities) to engage in activities or to have preferences unrelated to saleable products or services." C. Edwin Baker, Giving the Audience What It Wants, 58 Ohio St. L. L. J. 311, 406-407 (1997).

69. W. Brian Arthur, Beyond Rational Expectations: Indeterminacy in Economic and Financial Markets in The Frontiers of New Institutional Economics 293-294 (John N. Drobak \& John V.C. Nye, eds. 1997).

70. For a review of recent empirical literature that concluded that no conclusive evidence supports a claim that increased patent protection has increased innovation see Adam B. Jaffe, The U.S. Patent System in Transition: Policy Innovation and the Innovation Process, NBER Working Paper 7280 (August 1999). 


\section{Acknowledgments}

My thanks to Rochelle Dreyfuss, Mark Geistfeld, Mitu Gulati, Marcel Kahan, Lewis Kornhauser, Mark Ramseyer, Ricky Revesz, and Mike Schill who provided helpful comments on earlier drafts. The core arguments of the paper were presented at the Engelberg Center for Innovation Law and Policy conference, Intellectual Products: Novel Claims to Protection and Their Boundaries (La Pietra, Italy, June 25-27, 1998), and I thank the participants in the conference for their comments and thoughts. The research was supported by the Filomen D'Agostino and Max E. Greenberg Research Fund of the New York University School of Law. 